\title{
IMPLEMENTASI KLASIFIKASI DATA KEMACETAN ANGSURAN LEASING MOBIL DENGAN ALGORITMA C4.5
}

\author{
M. Edya Rosadi \\ (edya@fti.uniska-bjm.ac.id) \\ Nur Alamsyah \\ (alam@fti.uniska-bjm.ac.id) \\ Rahmadi Agus \\ (radizqi@fti.uniska-bjm.ac.id)
}

\begin{abstract}
ABSTRAK
Berkembangnya lembaga pembiayaan di Indonesia, jelas mempunyai masalah yang sering ditemui seperti masalah pembayaran angsuran yang tidak lancar atau macet. Banyaknya faktor yang memungkinkan kemacetan pembayaran angsuran dari debitur kepada perusahaan yang seharusnya sudah menjadi kewajiban sesuai perjanjian yang sudah disepakati. Berbagai penelitian yang telah dilakukan mengenai kemacetan ini banyak dilakukan berdasarkan dari data marketing. Oleh karena itu faktor penyebab kemacetan dalam penelitian ini berdasarkan dataset dari data debitur (aging collection). Penelitian ini mengklasifikasi kemacetan pada salah satu lembaga leasing menggunakan algoritma C4.5 untuk mengkaji hasil akurasi. Data yang digunakan data debitur PT. Olympindo tahun 2015 dimana dalam data tersebut adalah data yang menunjukan 2 kategori yaitu kategori macet dan lancar. Aplikasi yang digunakan adalah aplikasi Rapidminer. Hasil yang didapatkan dengan menggunakan algoritma C4.5 dapat mengklasifikasikan kredit lancar dan macet dengan akurasi sebesar 97,22\%.
\end{abstract}

Kata Kunci : Leasing, Klasifikasi, Algoritma C4.5

\section{PENDAHULUAN}

Tidak dapat dipungkiri industri otomotif sangat berkembang, khususnya di Indonesia. Perkembangan yang pesat ini dapat dilihat dari banyaknya dealer atau showroom mobil yang mewabah di daerahdaerah, apalagi daerah yang mulai berkembang. Naiknya penjualan mobil di Indonesia belakangan ini tidak terlepas dari peran serta lembaga pembiayaan (leasing), yang memberikan alternatif kepemilikan mobil dengan mudah dengan berbagai pilihan uang muka yang bervariasi dari sangat rendah, sedang dan tinggi, juga angsuran yang ringan atau jangka waktu (tenor) yang cukup lama, belum lagi ditambah dengan bonus-bonus yang menarik sehingga membuat masyarakat semua golongan berkeinginan untuk dapat memilikinya.
Menurut Surat Keputusan Bersama Menteri Keuangan, Perindustrian dan Perdagangan No.1169/KMK.01/1991 tanggal 21 Nopember 1991 tentang kegiatan Sewa Guna Usaha, Leasing (Noerlina, 2007) [1] adalah setiap kegiatan pembiayaan perusahaan dalam bentuk penyediaan barang-barang modal untuk digunakan oleh suatu perusahaan untuk jangka waktu tertentu, berdasarkan pembayaran berkala disertai dengan hak pilih (opsi) bagi perusahaan tersebut untuk membeli barang-barang modal yang bersangkutan atau memperpanjang jangka waktu leasing berdasarkan nilai sisa yang telah disepakati. Sama halnya dengan lembaga keuangan lainnya, leasing juga tidak lepas dari permasalahanpermasalahan kredit. Masalah yang sering terjadi banyak disebabkan karena ulah 
konsumen, seperti konsumen yang dianggap layak ternyata mendapat kendala dalam membayar angsuran, ada juga yang sampai akhirnya mobil harus ditarik oleh perusahaan pemberi kredit, bahkan ada konsumen yang melarikan diri bersama dengan mobil yang belum selesai pembiayaan kreditnya. Munculnya permasalahan itu salah satunya diakibatkan karena ketidaktajaman analis kredit. Analis kredit tidak melakukan monitor secara berkala serta lemahnya pengawasan kredit setelah konsumen mendapatkan fasilitas, baik pengawasan langsung maupun administratif.

Sebuah lembaga pembiayaan dinilai sukses bukan hanya karena besarnya kredit yang disalurkan tapi bagaimana lembaga pembiayaan tersebut dapat dari awal meminimalkan resiko dari setiap kredit yang telah disalurkan, staf marketing dan analis kredit sangat berperan dalam mewujudkan sukses tidaknya suatu lembaga leasing, yang mana dua staf ini adalah merupakan pencari konsumen dan yang memberi keputusan kelayakan yang diajukan oleh konsumen.

Setelah dua staf tersebut diatas masih ada staf yang tidak kalah penting perannya dalam suatu lembaga leasing, Staff collection (penagihan). Staf ini termasuk sangat penting, karena staf inilah yang fokusnya kepada penagihan angsuran konsumen baik kredit itu lancar dan macet, maka staf ini harus diberikan perhatian yang lebih karena setelah marketing yang pertama bersentuhan dengan konsumen maka selanjutnya staf collection ini yang paling lama (sesuai tenor) bersentuhan langsung dengan konsumen dalam perihal penerimaan angsuran yang bisa berupa bukti transfer atau uang tunai. Staf collection ini juga yang sering menemukan dan mendapatkan masalah, baik masalah internal dari lembaga leasing atas kesalahan prosedur sampai permasalahan yang sangat ditakutkan lembaga leasing yaitu masalah kredit macet.

Kredit macet adalah suatu hal yang sangat lumrah ditemukan pada lembaga- lembaga leasing dengan ini penulis mencoba menganalisa kredit macet berdasarkan data aging dari leasing PT.Olympindo Indonesia, dan mencoba menelusuri faktor yang paling dominan yang menyebabkkan terjadinya kredit macet berdasarkan data aging collection dengan variabel antara lain: jumlah tanggungan, status perkawinan, pendidikan terakhir, jangka waktu kredit, keuntungan usaha atau gaji, pekerjaan, status kepemilikan rumah, tenor bulanan dan status kredit.

Penelitian terdahulu yang terkait dengan topik aplikasi metode klasifikasi data mining pada analisa resiko kredit telah banyak dilakukan seperti penelitian yang dilakukan oleh Jing-xian Zhao tentang pembuatan model kombinasi neural network dan decision tree untuk resiko kredit, penelitian yang dilakukan oleh Eliana Angelini tentang evaluasi resiko kredit dengan pendekatan neural network (Angelini, 2007) [2], Penelitian oleh Kin Keung Lai tentang analisa resiko kredit menggunakan reliability berbasis model ensemble neural network (Lai, 2006) [3].

Henny Leidiyana[4] mengatakan kredit merupakah masalah yang menarik untuk diteliti. Beberapa riset bidang komputer untuk mengurangi resiko kredit telah banyak dilakukan dalam rangka menghindarai kehancuran suatu perusahaan pembiayaan.

Pada penelitian ini digunakan salah satu metode pohon keputusan (decision tree) yakni algoritma C4.5 untuk menentukan klasifikasi kredit lancar dan macet, hasil penelitian ini diharapkan akan membantu dalam menanggulangi dan mencegah masalah di leasing yaitu kredit macet yang banyak terjadi di lembaga-lembaga leasing di Indonesia .

\section{RUMUSAN MASALAH}

Berdasarkan latar belakang diatas maka dalam penelitian ini dilakukan klasifikasi penyebab yang membuat konsumen tidak melaksanakan kewajiban sesuai perjanjian yang sudah disepakati 
oleh kedua belah pihak (kredit macet) berdasarkan variabel dari dataset aging collection PT. Olympindo Indonesia, dengan menerapkan algoritma C4.5.

\section{TUJUAN PENELITIAN}

Adapun tujuan yang dapat di ambil dari penelitian ini yakni adalah dapat mengklasifikasi penyebab kemacetan yang sering terjadi di lembaga leasing pada PT. Olympindo Indonesia berdasarkan variabel dari dataset yang ada.

\section{MANFAAT PENELITIAN}

Manfaat yang didapat dari penelitian ini adalah terklasifikasinya penyebab kemacetan yang terjadi pada lembaga leasing, yang kemudian dapat membantu bagi lembaga leasing.

\section{METODE PENELITIAN}

Metode penelitian yang dilakukan adalah metode penelitian eksperimen menggunakan aplikasi data mining Rapidminer, dengan tahapan penelitian seperti berikut:

\section{Pengumpulan Data (Data Gathering)}

Data yang digunakan dalam penelitian ini adalah laporan kredit PT. Olympindo Indonesia tahun 2015 periode bulan Januari sampai periode Desember, dengan jumlah data 1789 record.

\section{Pengolahan Data (Data Pre- processing)}

Agar hasil yang didapatkan dari eksperimen sesuai maka data yang telah didapatkan kemudian dilakukan pemprosesan terlebih dahulu, dari yang awal terdapat 1789 record, terdapat 987 data yang tidak sesuai, sehingga data yang dapat disimulasikan sebesar 802 record. Sedangkan atribut yang digunakan untuk mengklasifikasikan data kemacetan angsuran leasing mobil dalam penelitian ini adalah seperti berikut:

Tabel 1. Atribut yang dinilai

\begin{tabular}{|c|c|c|}
\hline Atribut & Nilai Angka & Kategori \\
\hline Jumlah & 1 & 1 \\
\hline
\end{tabular}

Jurnal Ilmiah Fakultas Teknik "Technologia"

\begin{tabular}{|c|c|c|}
\hline Tanggungan & 2 & 2 \\
\hline & 3 & 3 \\
\hline & 4 & 4 \\
\hline $\begin{array}{c}\text { Status } \\
\text { Perkawinan }\end{array}$ & - & Kawin \\
\hline & - & Belum Kawin \\
\hline $\begin{array}{c}\text { Pendidikan } \\
\text { Terakhir }\end{array}$ & SD-SMA & SMA \\
\hline & S1-S3 & S1 \\
\hline Jangka Waktu & 3 tahun & 36 \\
\hline & 4 tahun & 48 \\
\hline & 5 tahun & 60 \\
\hline $\begin{array}{c}\text { Keuntungan } \\
\text { Usaha / Gaji }\end{array}$ & - & - \\
\hline Pekerjaan & PNS & PNS \\
\hline & Non PNS & Swasta \\
\hline Status Rumah & - & Milik Sendiri \\
\hline & - & Sewa \\
\hline Bulanan & & - \\
\hline Status & & Lancar \\
\hline & & Macet \\
\hline
\end{tabular}

\section{Lokasi Penelitian}

Lokasi penelitian ini pada PT. Olympindo Indonesia, dengan mengambil data kredit nasabah tahun 2015 periode bulan Januari-Desember. 


\section{ANALISIS HASIL DAN PEMBAHASAN}

\section{Model Yang Terbentuk}

Simulasi Algoritma C4.5 dengan menggunakan aplikasi datamining Rapidminer kemudian membentuk model aturan sebagai berikut:

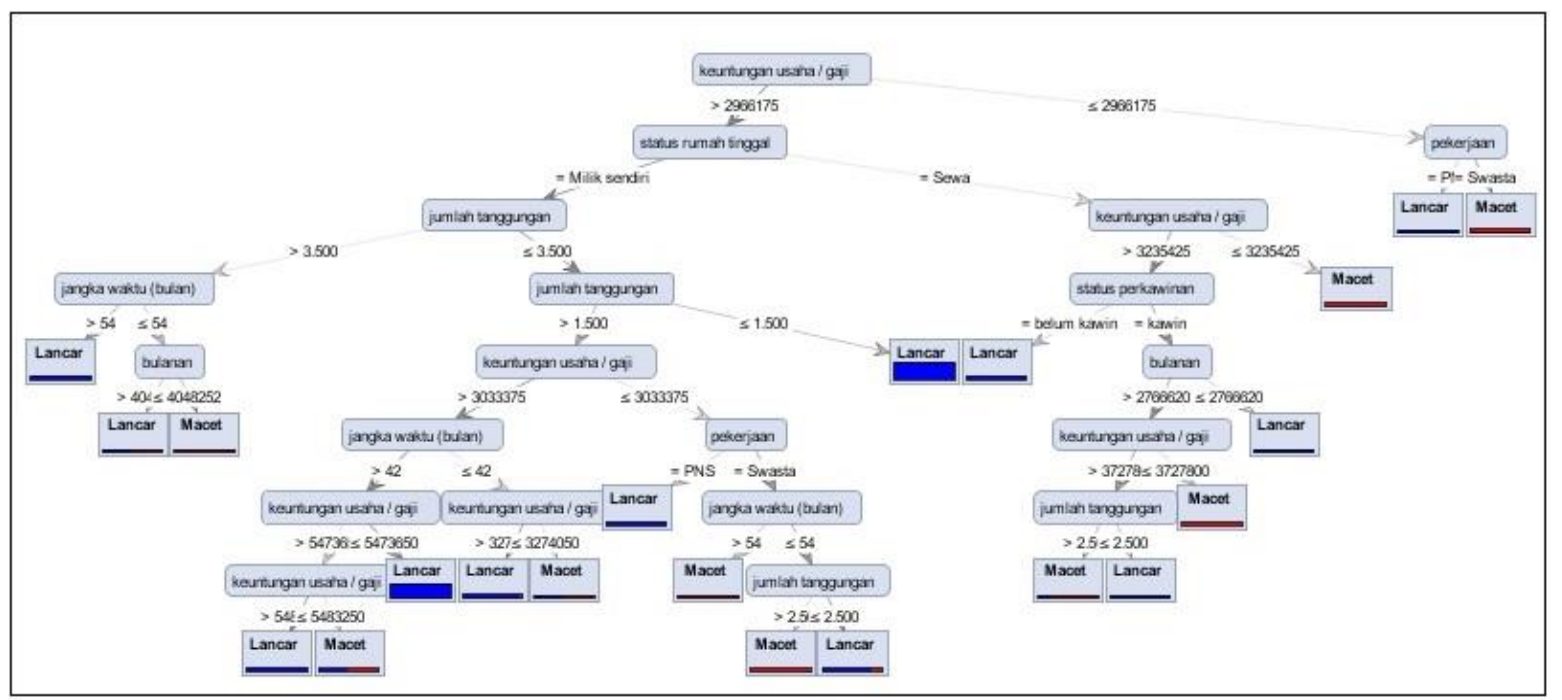

Gambar 1. Model yang terbentuk dari simulasi Rapidminer

\section{Hasil Pengujian}

Model pohon keputusan yang terbentuk dari algoritma C4.5 kemudian diuji keakuratannya dengan memasukkan ke sejumlah data uji. Teknik yang digunakan untuk pengujian akurasi dengan Confusion Matrix (Accuracy) dan ROC Curve (AUC).

Pengujian dengan confusion matrix menghasilkan tabel seperti di bawah ini:

Tabel .Pengujian dengan confusion matrix

\begin{tabular}{ccccc}
\hline & \multicolumn{2}{c}{ No Pruning } & \multicolumn{2}{c}{ Pruning } \\
\hline Min.Gain & ACC & AUC & ACC & AUC \\
0 & 97.10 & 0.847 & 97.10 & 0.906 \\
0.025 & 97.10 & 0.847 & 97.10 & 0.915 \\
0.05 & 97.22 & 0.814 & 97.22 & 0.917 \\
0.075 & 97.10 & 0.785 & 97.10 & 0.871 \\
0.1 & 96.75 & 0.811 & 96.75 & 0.842 \\
\hline & & & & \\
\hline
\end{tabular}

Jurnal Ilmiah Fakultas Teknik "Technologia" minimal gain 0.05 dengan pruning dengan besaran akurasi 97,22\%.

\section{PENUTUP}

Kesimpulan

Berdasarkan hasil eksperimen dan evaluasi yang dilakukan dapat disimpulkan bahwa algoritma C4.5 akurat dan dapat diterapkan untuk klasifikasi data kemacetan angsuran leasing mobil, dengan tingkat keakuratan 97,22\%.

\section{Saran}

Dengan menggunakan algoritma C4.5 tingkat keakuratan yang didapat sudah sangat tinggi, penelitian lebih lanjut dapat menambahkan metode optimasi seperti Ant Colony Optimization atau Particle Swarm Optimization. Selain itu juga dapat dilakukan penelitian dengan atribut lain yang berpengaruh terhadap kemacetan angsuran leasing mobil.

\section{DAFTAR PUSTAKA}

[1] P. Danenas and G. Garsva, "Credit risk 
evaluation modeling using evolutionary linear SVM classifiers and sliding window approach," International Conference on Computational Science, pp. 13241333, 2012.

[2] L. Yu, X. Yao, S. Wang and K. Lai, "Credit risk evaluation using a weighted least squares SVM classifier with design of experiment for parameter selection," Expert Systems with Applications, vol. 38, pp. 1539215399, 2011.

[3] Y. Peng and G. Kou, "A Comparative Study of Classification Methods in Financial Risk Detection," Fourth International Conference on Networked Computing and Advanced Information Management, vol. II, pp. 9-12, September 2008.

[4] L. Yu, G. Chen, A. Koronios, S. Zhu and X. Guo, "Application and Comparison of Classification Techniques in Controlling Credit Risk," Recent Advances in Data Mining of Enterprise Data : Algorithm and Application, vol. VI, pp. 111-145, 2007.

[5] Y. Liu, G. Wang, H. Chen, H. Dong, $\mathrm{X}$. Zhu and S. Wang, "An Improved Particle Swarm Optimization for Feature Selection," Journal of Bionic Engineering, pp. 191-200, 2011.

[6] Y. Jiang, "Credit Scoring Model Based on the Decision Tree and the Simulated Annealing Algorithm," World Congress on Computer Science and Information Engineering, pp. 1822, April 2009.

[7] H. Yu, X. Huang, X. Hu and H. Cai, "A Comparative Study on Data Mining Algorithms for Individual Credit Risk Evaluation," International Conference on Management of $e$ Commerce and e-Government, pp. 35-
38, October 2010.

[8] D. T. Larose, Discovering knowledge in data : an introduction to data mining, New Jersey: Wiley, 2005.

[9] J. Han and M. Kamber, Data Mining : Concepts and Techniques, Second ed., M. R. Jim Gray, Ed., San Francisco: Morgan Kaufmann Publishers, 2007.

[10] K. and E. T. Luthfi, Algoritma Data Mining, Yogyakarta: Andi, 2009.

[11] I. H. Witten, E. Frank and M. A. Hall, Data Mining Practical Mechine Learning Tools And Technique, Burlington: Elsevier Inc, 2011.

[12] J. Kennedy and R. Eberhart, "Particle Swarm Optimization," Proceedings of IEEE International Conference on Neural Network, pp. 1942-1948, 1995.

[13] C. Vercellis, Business Intelligence : Data Mining and Optimization for Decision Making, John Wiley \& Sons Inc, 2009.

[14] F. Gorunescu, Data Mining Concepts, Models and Techniques, SpringerVerlag, 2011.

[15] C. Zhu, Y. Zhan and S. Jia, "Credit Risk Identification of Bank Client Basing on Supporting Vector 6] Machines," International Conference on Business Intelligence and Financial Engineering, pp. 62-66, August 2010.
N. Fahmi, Analisis dan Komparasi Metode Klasifikasi Data Mining untuk Penentuan Resiko Kredit, Semarang, 2011.

[17] I. H. Witten, Data Mining : Practical Machine Learning Tools and Techniques, Second ed., San Francisco: Morgan Kaufmann Publishers, 2005. 